\title{
THE STUDY OF POSSIBILITIES FOR REUSE OF WASHINGS FROM SWIMMING POOL CIRCULATION SYSTEMS
}

\author{
BADANIA MOŻLIWOŚCI ZAGOSPODAROWANIA POPLUCZYN \\ Z OBIEGÓW BASENOWYCH
}

\begin{abstract}
Swimming pools are very expensive, in terms of operation, sports facilities. Therefore, investors and managers of these facilities are looking for methods of reducing the costs of their use. One of the proposed methods is the managing of washings previously discharged to the sanitary sewage system. The assessment of possibilities for reuse of washings from swimming pool filtration system is based on the limits of basic indicators of pollutants in wastewater discharged to water and soil (temperature, $\mathrm{pH}, \mathrm{TSS}, \mathrm{BOD}_{5}, \mathrm{COD}, \mathrm{TN}$, TP, free chlorine). The conducted research of washings quality from 26 tested swimming pools have shown that washings quality is dependent on the operating conditions of the pool circuit, including the filter cycle duration and types of filter bed. A direct discharge to water or soil may be impossible due to excessive amounts of total suspended solids (above $35 \mathrm{mg} / \mathrm{dm}^{3}$ ) and free chlorine concentration (above $0.2 \mathrm{mg} \mathrm{Cl}_{2} / \mathrm{dm}^{3}$ ). However, the quality of supernatant water of washings subjected to sedimentation in the laboratory shows that the washings are suitable for reuse. The installation of settling tanks in swimming pool facilities could relieve the sewage systems and allow for the discharge of supernatant water to surface waters or for the irrigation of green areas in an environmentally friendly way.
\end{abstract}

Keywords: washings, swimming pool water circulation system, washings reusing, sedimentation

\section{Introduction}

Technologies for recovering water from washings discharged from water treatment stations have been used in Poland and all over the world for many years [1-10].

In Poland, issues connected with the management of washings from swimming pool treatment systems have been pondered upon for about 10 years, since increasingly high prices for water and sewage started to convince swimming pool owners to look for solutions that would reduce the costs of running their facilities. One of them is the management of washings that have usually been discharged to the sewage system.

Since 2002, the Institute of Water and Wastewater Engineering of Silesian University of Technology is testing the quality of washings discharged from pools filtration systems and the possibility of their management $[11,12]$. The main idea is the rational use of

\footnotetext{
${ }^{1}$ Institute of Water and Wastewater Engineering, Silesian University of Technology, ul. S. Konarskiego 18, 44-100 Gliwice, Poland, phone +48 3223722 43, fax +48 3223710 47, email: joanna.wyczarska-kokot@ polsl.pl
} 
existing easy solutions, processes and devices, eg sedimentation tanks, settling tanks or settling tanks combined with flocculent mixing tank.

In the case of washings coming from cleaning the pools filter beds, potential is hidden in their large volume and the simplicity of methods that are used to recover the supernatant water.

The proper rinsing of a swimming pool filter requires from 4 to $6 \mathrm{~m}^{3}$ of water per $\mathrm{m}^{2}$ of filter bed [13-16]. For example, swimming pool treatment system consisting of 2 filters with diameter of $1800 \mathrm{~mm}$, that are usually rinsed every two days, requires from 245 to $365 \mathrm{~m}^{3}$ of water every month, just for cleaning it.

Taking into account the fact that there are 736 public indoor swimming pools in Poland [17], each with a few or several filtration systems, and that the demand of water for those facilities is high, the idea of washings reuse is certainly worth considering. The studies of the volume of washings discharged to the sewage system conducted so far showed that it is possible to reduce the costs for sewage by $20-70 \%$. Sometimes, the volume of washings was not as important as the price for discharging $1 \mathrm{~m}^{3}$ of washings [11, 12].

With the proper quality of swimming pool water [13-16, 18] and efficient pool filtration systems $[19,20]$, using the supernatant water from washings for irrigating green areas, sprinkling grounds and tennis courts (very often located near a swimming pool), as well as flushing toilets is an easy solution that allows to dramatically reduce the cost of water and sewage.

If a swimming pool is located near a watercourse, washings could be discharged directly to it. It should be noted that operating an installation for discharging washings into a watercourse requires a water permit that regulates the use of water and discharge of sewage into water or soil [21-23]. Special attention should be paid to the level of washings contamination as compared to the cleanliness class of the chosen watercourse and the method of discharging wastewater into a receiving body of water [24, 25].

The simple solutions for the management of washings are gaining in popularity among the swimming pool owners. A few of the tested facilities have them already and the cost of their implementation is being recovered.

In the case of new swimming pools, the installations for washings reuse are often planned during the design stage.

The main objective of this article is to assess the basic parameters of washings quality and to determine the possibility of their management with the help of simple and environmentally friendly methods. This is achieved by analysing the results of physicochemical tests of washings samples taken from 26 filtration systems in years 2002-2015.

\section{Research methodology}

The research compares the results of physiocochemical analysis against the regulations and recommendations concerning the permitted level of pollutants in wastewater discharged to water or soil [21, 23-25].

The analytical tests of basic quality parameters of washings were performed: $\mathrm{pH}$, temperature, total suspended solids, COD (chemical oxygen demand), $\mathrm{BOD}_{5}$ (the five-day biochemical oxygen demand), total nitrogen, total phosphorus, free chlorine and, in 11 samples of washings, CFU (colony forming units) of total bacterial count. 
The maximum allowable values of pollutants, presented in Table 1, were considered the basis for determining if the washings could be reused by discharging them to water or soil.

The analysis covered raw washings and washings subjected to a two-hour sedimentation process in laboratory conditions.

The complete cycle of tests for determining the contamination level of washings from particular pool circuits took from 1 to 2 months. Eight basic tests were performed. These determined the sedimentation efficiency, washings contamination level and their suitability for reuse.

Table 1

Maximum allowable values of selected indicators of contaminants in wastewater discharged to water or soil by [24]

\begin{tabular}{|c|c|c|c|c|}
\hline No. & Indicator & Unit & $\begin{array}{c}\text { Maximum } \\
\text { allowable value }\end{array}$ & $\begin{array}{c}\text { Minimum percentage } \\
\text { of pollution reduction [\%] }\end{array}$ \\
\hline 1 & $\mathrm{pH}$ & {$[-]$} & $6.5-9.0$ & - \\
\hline 2 & Temperature & {$\left[{ }^{\circ} \mathrm{C}\right]$} & 35 & - \\
\hline 3 & Total suspended solids & {$\left[\mathrm{mg} / \mathrm{dm}^{3}\right]$} & 35 & 90 \\
\hline 4 & Chemical oxygen demand COD & {$\left[\mathrm{mg} \mathrm{O}_{2} / \mathrm{dm}^{3}\right]$} & 125 & 75 \\
\hline 5 & $\begin{array}{l}\text { The five-day biochemical oxygen } \\
\text { demand } \mathrm{BOD}_{5}\end{array}$ & {$\left[\mathrm{mg} \mathrm{O}_{2} / \mathrm{dm}^{3}\right]$} & 25 & $70-90$ \\
\hline 6 & Total nitrogen & {$\left[\mathrm{mg} \mathrm{N} / \mathrm{dm}^{3}\right]$} & 15 & - \\
\hline 7 & Total phosphorus & 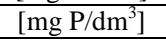 & 2 & - \\
\hline 8 & Free chlorine & {$\left[\mathrm{mg} \mathrm{Cl}_{2} / \mathrm{dm}^{3}\right]$} & 0.2 & - \\
\hline
\end{tabular}

The washings were collected in batch during the whole cycle of filter beds rinsing (mean mixed sample) through valves installed on the pipes of individual filters.

The samples were collected and marked in accordance with applicable standards and methods [26-29]. PH was determined by potentiometric method, temperature by direct measurement method, total suspended solids by direct weigh method, COD, total phosphorus, total nitrogen and free chlorine by spectrophotometrical method (spectrophotometer DR5000 UV/VIS), $\mathrm{BOD}_{5}$ by dilution method (measuring device Oxi Top ${ }^{\circledR}$ OC 100), the total number of organisms was determined in the accredited laboratory of District Sanitary-Epidemiological Station.

The analysis and comparison of washings test results showed that direct discharge to water or soil was impossible due to excessive amounts of total suspended solids and free chlorine concentration.

The analysis of test results of washings after the sedimentation process allowed to establish if they could be discharged into watercourses or used for the irrigation of green areas. Both manners of management required the installation of a settling tank and/or system for facilitating the sedimentation of suspended solids, and then the discharge of the condensed sewage to the sewage system.

\section{Characteristics of swimming pool filtration cycles}

The washings samples under study come from 26 pool cycles, 16 from sports pools and 10 from relaxation pools. The pool cycles (swimming pools) are marked: B1, B2, B3, etc. to B26. All of the analyzed pools are public indoor swimming pools, designed for bathing, irrespective of weather conditions. Water treatment for all cycles is based on 
processes performed in close water cycles, inculding active overflow, and consists of: prefiltration - surface coagulation (except cycles B14 and B17 which use diatomaceous filters) - disinfection (mainly $\mathrm{NaOCl}$, in a few pools supported with UV irradiation or partial water ozonization) - $\mathrm{pH}$ adjustment.

Among the analyzed pools, 16 are typical sports pools with dimensions of $12.5 \mathrm{~m} \times 25 \mathrm{~m}, 10$ are recreational pools designed mainly for children, with irregular shapes and of various sizes. Pools B14 and B17 use open vaccuum filters pre-coated with diatomaceous earth. Here, the water is filtered with a speed of $2.5-4.0 \mathrm{~m} / \mathrm{h}$, and rinsing consists of removing diatomaceous earth with the help of high-pressure water from the mains. Depending on the number of filter cartridges, one rinsing requires from 3 to $7 \mathrm{~m}^{3}$ of water.

The remaining cycles are equipped with closed pressure filters that filter the cycle water with a speed of $30 \mathrm{~m} / \mathrm{h}$, and rinse the filter beds with a speed of $60-65 \mathrm{~m} / \mathrm{h}$. Rinsing requires from $4-6 \mathrm{~m}^{3}$ of water per $\mathrm{m}^{2}$ of filter bed. The water for rinsing is taken from expansion tanks.

The pools under study are supplied with water from the mains water supply complying with quality requirements of water for consumption, $30 \mathrm{dm}^{3}$ per every bathing person and per 24 hours. Sewage and washings are discharged to the external sewage system. Due to insufficient capacity of urban sewage systems to which washings from B3, B4, B5, B18, B19, B20, B21 and B26 are discharged, the water treatment systems in these facilities were equipped with buffer tanks allowing for storage and then successive discharge of washings to the sewers. In pools B4, B5, B18, B21 and B26, these tanks serve as settling tanks for washings, allowing for their partial recovery.

The characteristics of filtration cycles, from which washings samples were taken, are presented in Table 2.

Table 2

Characteristics of tested filtration cycles

\begin{tabular}{|c|c|c|c|c|c|}
\hline $\begin{array}{l}\text { Swimming } \\
\text { pool }\end{array}$ & $\begin{array}{c}\text { Number } \\
\text { of filters } \\
\text { [item] }\end{array}$ & $\begin{array}{c}\text { Filter diameter } \\
\text { or width } \times \text { length } \\
{[\mathrm{mm}]}\end{array}$ & $\begin{array}{l}\text { The height of the } \\
\text { filter layer [mm] }\end{array}$ & Type of filter bed & $\begin{array}{c}\text { Cycle time } \\
\text { of filtration } \\
\text { [day] }\end{array}$ \\
\hline B1 & 1 & 1800 & 1200 & \multirow{2}{*}{ sand multilayer } & 1 \\
\hline B2 & 3 & 1800 & 1200 & & 2 \\
\hline B3 & 2 & 1800 & 1200 & $\begin{array}{l}\text { sand multilayer with a layer } \\
\text { of anthracite }\end{array}$ & 2 \\
\hline B4 & 1 & 1800 & 1500 & \multirow{2}{*}{ sand multilayer } & 1 \\
\hline B5 & 2 & 1800 & 1500 & & 2 \\
\hline B6 & 2 & 1800 & 1200 & \multirow{6}{*}{$\begin{array}{l}\text { sand multilayer with a layer } \\
\text { of anthracite }\end{array}$} & 2 \\
\hline B7 & 2 & 1600 & 1500 & & 3 \\
\hline B8 & 2 & 1800 & 1500 & & 3 \\
\hline B9 & 2 & 765 & 1250 & & 3 \\
\hline B10 & 2 & 1800 & 1350 & & 2 \\
\hline B11 & 2 & 1800 & 1200 & & 3 \\
\hline B12 & 2 & 1800 & 1500 & sand multilayer & 2 \\
\hline B13 & 2 & 1600 & 1200 & $\begin{array}{c}\text { sand multilayer with a layer } \\
\text { of anthracite }\end{array}$ & 3 \\
\hline B14 & 1 & $2000 \times 1900$ & 2000 & diatomaceous earth & $7-10$ \\
\hline B15 & 2 & 2000 & 1200 & $\begin{array}{l}\text { sand multilayer with a layer } \\
\text { of anthracite }\end{array}$ & 3 \\
\hline B16 & 2 & 1800 & 1500 & $\begin{array}{l}\text { sand multilayer with a layer } \\
\text { of active carbon }\end{array}$ & 2 \\
\hline
\end{tabular}




\begin{tabular}{|c|c|c|c|c|c|}
\hline $\begin{array}{l}\text { Swimming } \\
\text { pool }\end{array}$ & $\begin{array}{c}\text { Number } \\
\text { of filters } \\
\text { [item] }\end{array}$ & \begin{tabular}{|c|} 
Filter diameter \\
or width $\times$ length \\
{$[\mathrm{mm}]$}
\end{tabular} & $\begin{array}{l}\text { The height of the } \\
\text { filter layer [mm] }\end{array}$ & Type of filter bed & $\begin{array}{c}\text { Cycle time } \\
\text { of filtration } \\
\text { [day] }\end{array}$ \\
\hline B17 & 1 & $2100 \times 2300$ & 2000 & diatomaceous earth & $6-8$ \\
\hline B18 & 2 & 1800 & 1500 & $\begin{array}{c}\text { sand multilayer with a layer } \\
\text { of anthracite }\end{array}$ & 7 \\
\hline B19 & 2 & 1800 & 1200 & \multirow{2}{*}{ sand multilayer } & 3 \\
\hline $\mathrm{B} 20$ & 1 & 1400 & 1200 & & 2 \\
\hline B21 & 2 & 2200 & 1500 & $\begin{array}{l}\text { sand multilayer with a layer } \\
\text { of anthracite }\end{array}$ & 2 \\
\hline $\mathrm{B} 22$ & 1 & 1600 & 1200 & AFG (a bed of glass) & 1 \\
\hline B23 & 2 & 1800 & 1200 & \multirow{3}{*}{$\begin{array}{c}\text { sand multilayer with a layer } \\
\text { of anthracite }\end{array}$} & 3 \\
\hline B24 & 2 & 1600 & 1200 & & 3 \\
\hline $\mathrm{B} 25$ & 1 & 800 & 1200 & & 1 \\
\hline $\mathrm{B} 26$ & 1 & 910 & 1200 & sand multilayer & 1 \\
\hline
\end{tabular}

\begin{tabular}{|c|c|c|c|c|c|}
\hline $\begin{array}{l}\text { Swimming } \\
\text { pool }\end{array}$ & $\begin{array}{c}\text { Filtration } \\
\text { surface } \\
{\left[\mathrm{m}^{2}\right]} \\
\end{array}$ & Rinsing method & $\begin{array}{c}\text { Circuit efficiency } \\
{\left[\mathrm{m}^{3} / \mathrm{h}\right]}\end{array}$ & $\begin{array}{c}\text { The number } \\
\text { of rinses in } \\
\text { month }\end{array}$ & $\begin{array}{l}\text { The volume } \\
\text { of washings } \\
\left.\text { [ } \mathrm{m}^{3} / \mathrm{month}\right]\end{array}$ \\
\hline B1 & 2.54 & \multirow{8}{*}{$\begin{array}{l}\text { compressed air and water } \\
\text { from the retention tank }\end{array}$} & 76.3 & 12 & 182.9 \\
\hline B2 & 2.54 & & 228.9 & 24 & 365.8 \\
\hline B3 & 2.54 & & 152.6 & 24 & 365.8 \\
\hline B4 & 2.54 & & 76.3 & 12 & 182.9 \\
\hline B5 & 2.54 & & 152.6 & 24 & 365.8 \\
\hline B6 & 2.54 & & 146 & 16 & 243.8 \\
\hline B7 & 2.01 & & 120 & 24 & 289.4 \\
\hline B8 & 2.54 & & 152.6 & 16 & 243.8 \\
\hline B9 & 0.46 & $\begin{array}{l}\text { water from the retention } \\
\text { tank }\end{array}$ & 46 & 16 & 44.2 \\
\hline B10 & 2.54 & \multirow{4}{*}{$\begin{array}{l}\text { compressed air and water } \\
\text { from the retention tank }\end{array}$} & 146 & 16 & 243.8 \\
\hline B11 & 2.54 & & 140 & 16 & 243.8 \\
\hline B12 & 2.54 & & 152.6 & 16 & 243.8 \\
\hline B13 & 2.01 & & 120 & 16 & 193.0 \\
\hline B14 & $\begin{array}{c}3.60 \\
(1 \text { inset })\end{array}$ & tap water & 110 & 4 & 28.0 \\
\hline B15 & 3.14 & \multirow{2}{*}{$\begin{array}{l}\text { compressed air and water } \\
\text { from the retention tank }\end{array}$} & 188.6 & 16 & 301.4 \\
\hline B16 & 2.54 & & 152.6 & 24 & 365.8 \\
\hline B17 & $\begin{array}{c}4.83 \\
(1 \text { inset })\end{array}$ & tap water & 174 & 5 & 35.0 \\
\hline B18 & 2.54 & \multirow{7}{*}{$\begin{array}{l}\text { compressed air and water } \\
\text { from the retention tank }\end{array}$} & 142 & 4 & 61.0 \\
\hline B19 & 2.54 & & 152.6 & 16 & 243.8 \\
\hline $\mathrm{B} 20$ & 1.54 & & 46 & 15 & 138.6 \\
\hline B21 & 3.8 & & 115 & 24 & 547.2 \\
\hline B22 & 2.01 & & 60 & 30 & 361.8 \\
\hline B23 & 2.54 & & 152.6 & 24 & 365.8 \\
\hline B24 & 2.01 & & 120 & 24 & 289.4 \\
\hline B25 & 0.5 & \multirow{2}{*}{$\begin{array}{l}\text { water from the retention } \\
\text { tank }\end{array}$} & 15 & 30 & 90.0 \\
\hline B26 & 0.65 & & 23 & 30 & 117.0 \\
\hline
\end{tabular}

\section{Analysis of research results}

The analysis of physicochemical properties of washings discharged from the tested swimming pools showed that these washings must not be discharged directly to water and soil due to the exceeded content of total suspended solids, $\mathrm{COD}$ and $\mathrm{BOD}_{5}$ and the concentration of free chlorine. 
The average content of total suspended solids in the tested washings ranged from $24 \mathrm{mg} / \mathrm{dm}^{3}$ in swimming pool B26 to $1615 \mathrm{mg} / \mathrm{dm}^{3}$ in swimming pool B17 whereas the allowed limit of suspended solids for sewage discharged into water and soil is $35 \mathrm{mg} / \mathrm{dm}^{3}$ (Fig. 1).

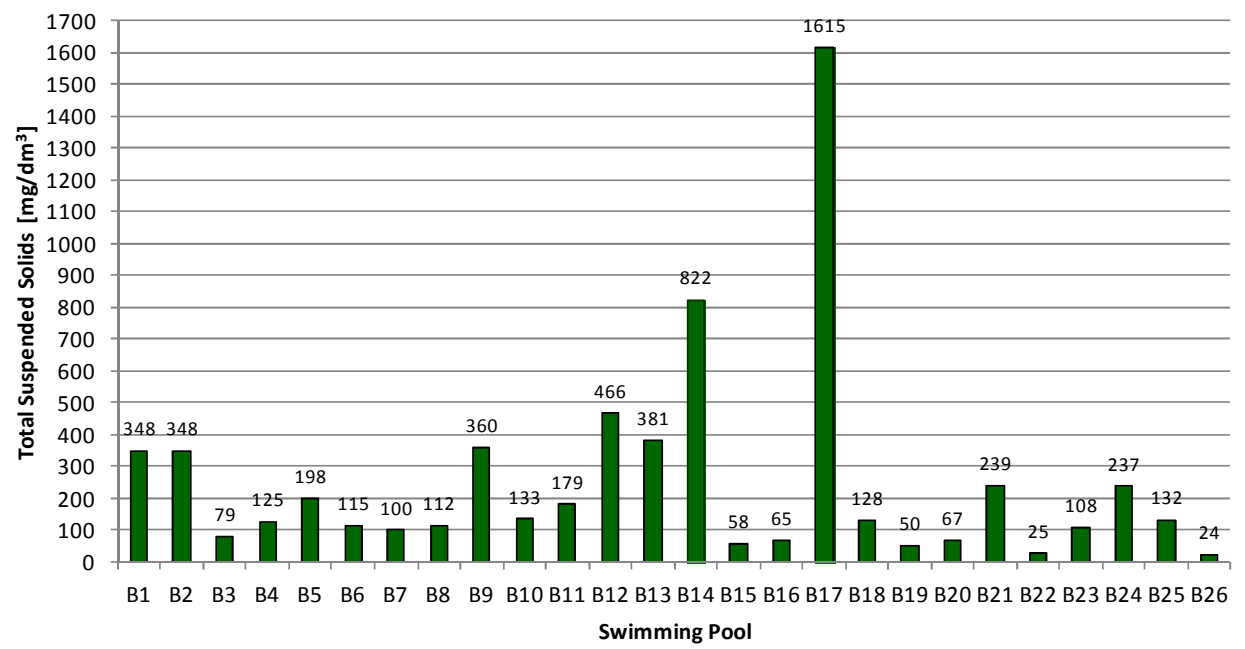

Fig. 1. The amount of total suspended solids in washings discharged from tested pools

A two-hour sedimentation process resulted in the reduction of total suspended solids in the tested washings, ranging from $24.0 \%$ in B19 to $95.4 \%$ in pool B1. As a result, the amount of settle-resistant suspended solids in supernatant water ranged from $14 \mathrm{mg} / \mathrm{dm}^{3}$ in B21 to $150 \mathrm{mg} / \mathrm{dm}^{3}$ in B14 (Fig. 2).

Washings from B14 and B17 pool circuits contained the highest amount of total suspended solids (on average: 822 and $1615 \mathrm{mg} / \mathrm{dm}^{3}$ ). Such a high level of suspended solids in the washings is caused by the filtration systems and rinsing method. Both circuits have vacuum filters with filter cloths pre-coated with powdered diatomaceous earth. The filters are cleaned by removing the contaminants together with diatomaceous earth, what is responsible for such a high content of suspended solids in washings discharged from the circuits. In both cases, despite the high reduction of suspended solids during the sedimentation process (81.7\% in B14 and $95.0 \%$ in B17), the amount of settle-resistant suspended solids was still very high $\left(80 \mathrm{mg} / \mathrm{dm}^{3}\right.$ in B17 and $150 \mathrm{mg} / \mathrm{dm}^{3}$ in B14).

In washings from circuits B6, B10, B17, B18 and B20, the observed reduction of suspended solids ranged only between: $24.0 \%$ (B19)-58.5\% (B18). Such low reduction level was caused by the low efficiency of the coagulation process. Light and very small flocs found in the washings from these swimming pools did not settle and after a two-hour sedimentation process there was on average from $38 \mathrm{mg} / \mathrm{dm}^{3}$ (B19) to $56 \mathrm{mg} / \mathrm{dm}^{3}$ (B10) of settle-resistant suspended solids in the supernatant water.

In the remaining samples of washings that were subjected to the sedimentation process, the amount of total suspended solids in the supernatant water ranged from $14 \mathrm{mg} / \mathrm{dm}^{3}$ in $\mathrm{B} 21$ to $35 \mathrm{mg} / \mathrm{dm}^{3}$ in B5 and B15. 


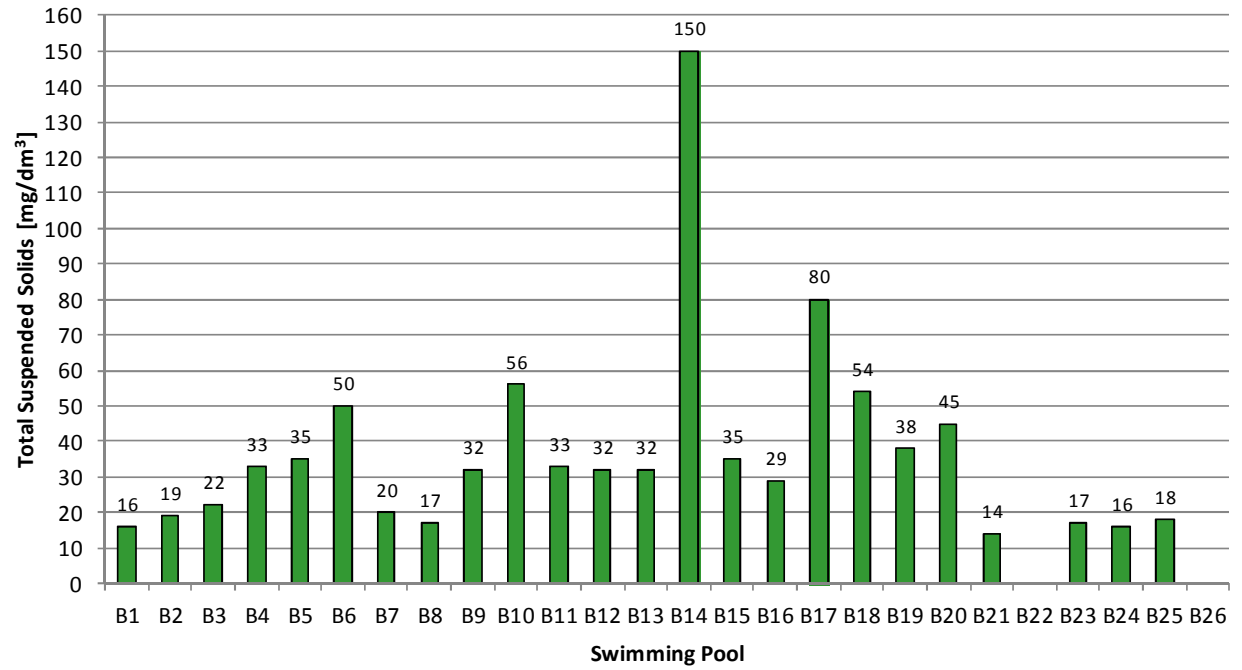

Fig. 2. The amount of total suspended solids in supernatant water after a two-hour process of washings sedimentation

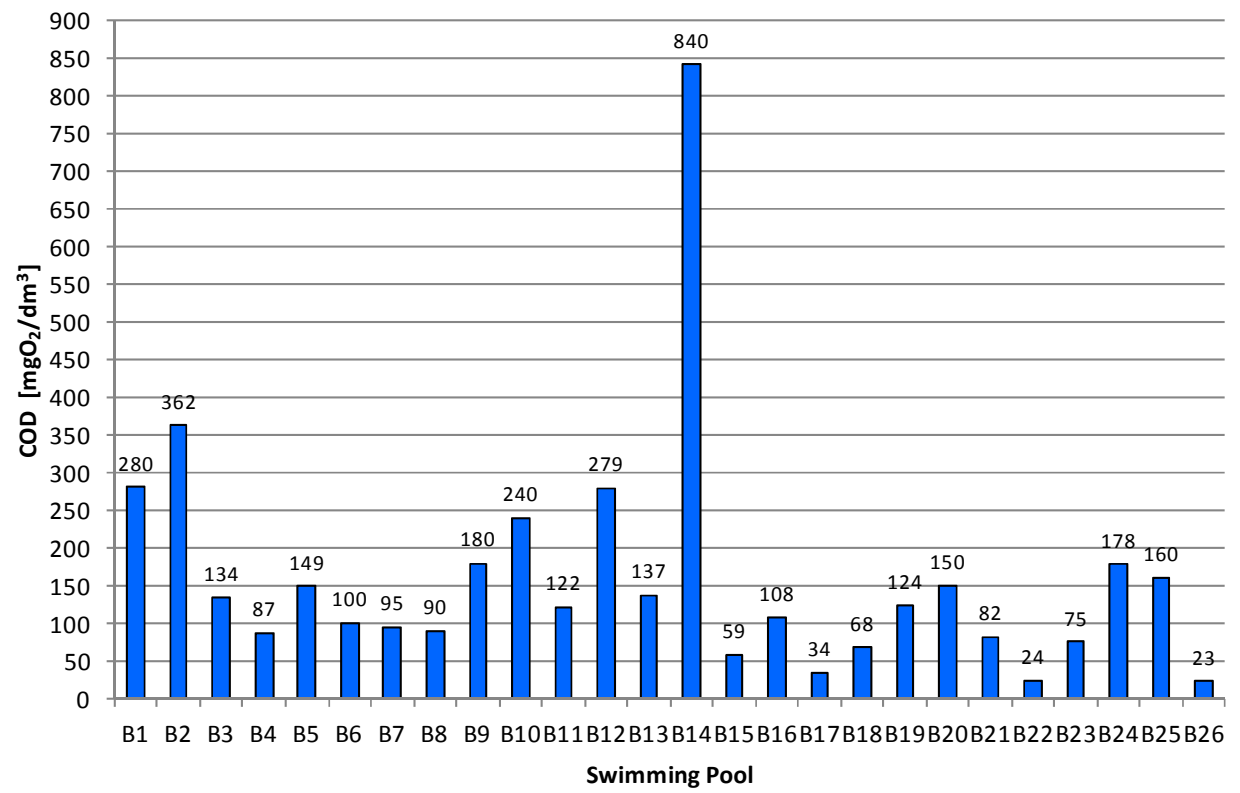

Fig. 3. COD in washings discharged from tested pools

In the tested washings, the average values of COD ranged from $23 \mathrm{mg} \mathrm{O} / \mathrm{dm}^{3}$ in $\mathrm{B} 26$ pool cycle to $840 \mathrm{mg} \mathrm{O} / \mathrm{dm}^{3}$ in B14 (Fig. 3). In the washings from 14 pools, the value of this indicator did not exceed the limit for sewage discharged to water and soil 
$\left(125 \mathrm{mg} \mathrm{O} \mathrm{O}_{2} / \mathrm{dm}^{3}\right)$. The sedimentation process resulted in the reduction of COD values, ranging from $29.4 \%$ in washings from B18 to $97.0 \%$ in B2. As a result, after a two-hour sedimentation process, COD values in the supernatant water did not exceed $125 \mathrm{mg} \mathrm{O} / 2 \mathrm{dm}^{3}$ and ranged from $11 \mathrm{mg} \mathrm{O}_{2} / \mathrm{dm}^{3}$ in $\mathrm{B} 2$ and B17 to $112 \mathrm{mg} \mathrm{O}_{2} / \mathrm{dm}^{3}$ in B14 (Fig. 4).

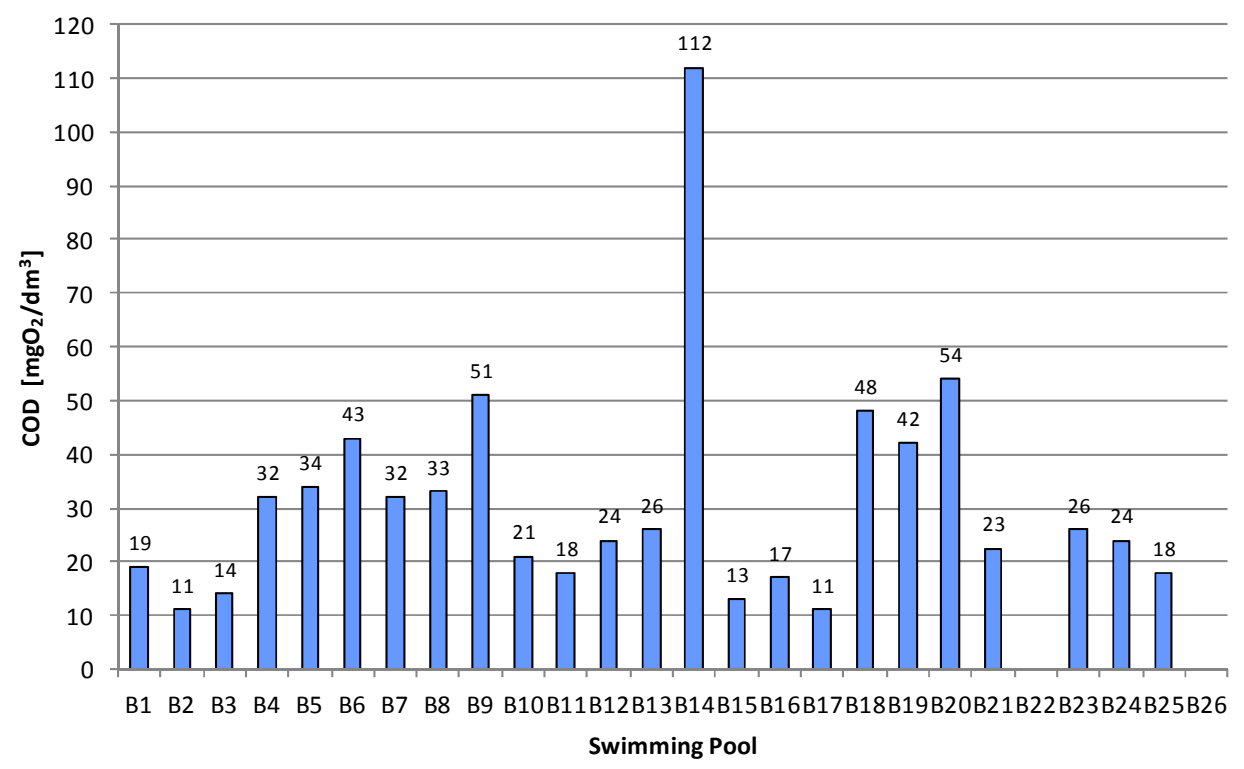

Fig. 4. COD in supernatant water after a two-hour process of washings sedimentation

The average values of $\mathrm{BOD}_{5}$ in the tested washings ranged from $0.8 \mathrm{mg} \mathrm{O} / \mathrm{dm}^{3}$ in $\mathrm{B} 26$ to $66.7 \mathrm{mg} \mathrm{O}_{2} / \mathrm{dm}^{3}$ in $\mathrm{B} 2$. In the washings from 22 pools, the value of this indicator did not exceed the limit for sewage discharged to water and soil $\left(25 \mathrm{mg} \mathrm{O}_{2} / \mathrm{dm}^{3}\right)$. The sedimentation process (in $\mathrm{B} 1-\mathrm{B} 21$ ) resulted in the reduction of $\mathrm{BOD}_{5}$ values, ranging from $32.5 \%$ in pool $\mathrm{B} 14$ to $88.3 \%$ in pool $\mathrm{B} 2$, what in turn allowed to reach $\mathrm{BOD}_{5}$ values ranging from $1.8 \mathrm{mg} \mathrm{O}_{2} / \mathrm{dm}^{3}$ in $\mathrm{B} 20$ to $14.8 \mathrm{mg} \mathrm{O}_{2} / \mathrm{dm}^{3}$ in $\mathrm{B} 13$ (Fig. 5).

The average values of total phosphorus in the tested washings did not exceed $2 \mathrm{mg} \mathrm{P} / \mathrm{dm}^{3}$ with the exception of washings discharged from B14 and B16 in which case the average values of total phosphorus amounted to, respectively, $2.03 \mathrm{mg} \mathrm{P} / \mathrm{dm}^{3}$ and $2.30 \mathrm{mg} \mathrm{P} / \mathrm{dm}^{3}$ (Fig. 6).

The average values of total nitrogen in the tested washings ranged from $3.7 \mathrm{mg} \mathrm{N} / \mathrm{dm}^{3}$ in B22 to $26.2 \mathrm{mg} \mathrm{N} / \mathrm{dm}^{3}$ in B25. With the exception of washings discharged from B9, B14, B20 and B25, the amount of total nitrogen in washings did not exceed the limit for sewage discharged to water and soil, ie $15 \mathrm{mg} \mathrm{N} / \mathrm{dm}^{3}$ (Fig. 7). 


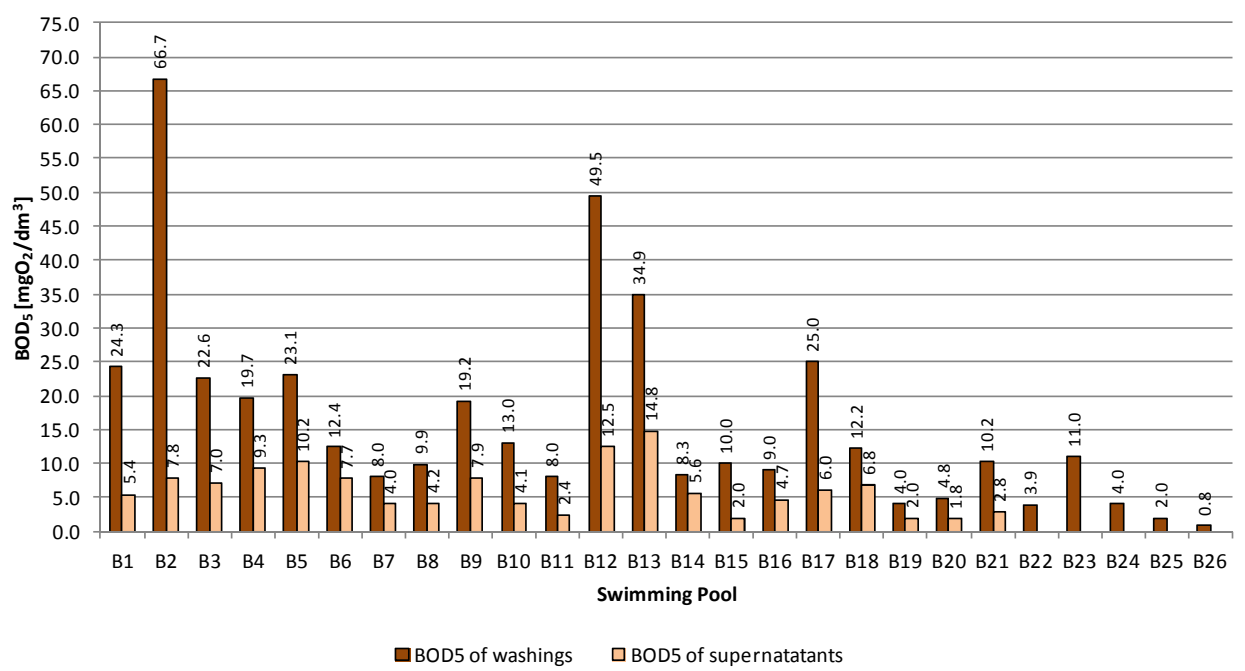

Fig. 5. $\mathrm{BOD}_{5}$ in the washings and supernatant water after a two-hour sedimentation process

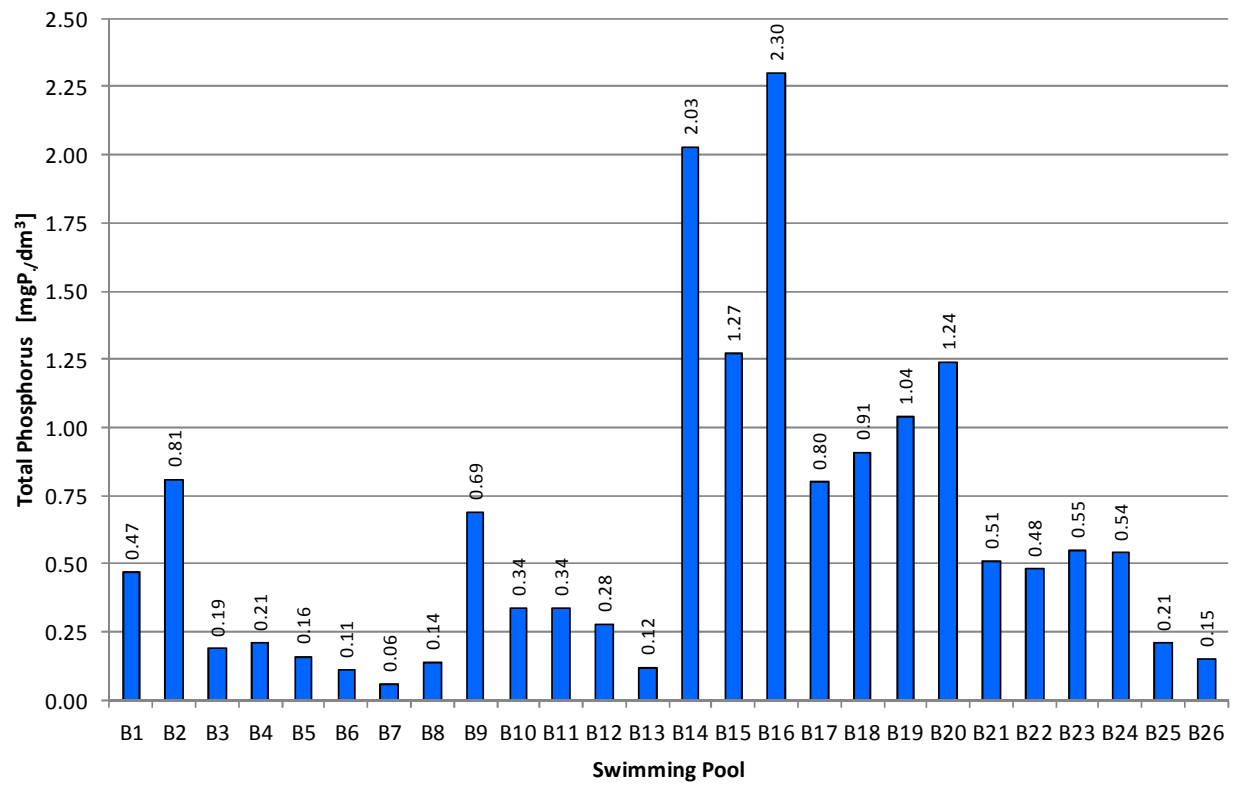

Fig. 6. The content of total phosphorus in the washings discharged from tested pools

The assessment of possibilities of washings management depends also on $\mathrm{pH}$ and temperature of washings. The tested washings $\mathrm{pH}$ values ranged from 6.74-8.59 (average value $\mathrm{pH}=7.31$ ). The washings temperature depended mainly on the temperature of water that was used to rinse filter beds. The beds of pressure multimedia filters (using sand or 
sand and anthracite) were rinsed with water taken from pool expansion tanks, that is with water whose temperature ranged from $26-30^{\circ} \mathrm{C}$ (depending on the pool type). That is why the temperature of washings after rinsing of this type of beds ranged from $22.1-30.0^{\circ} \mathrm{C}$ (depending on the time that has elapsed since the tank was filled with water from the mains water supply). Diatomeous filters were rinsed with water from the mains water supply, that is with water whose temperature ranged from $12-18^{\circ} \mathrm{C}$. That is why the average temperature of washings coming from cleaning the filter cloths pre-coated with diatomaceous earth was $15.5^{\circ} \mathrm{C}$ in $\mathrm{B} 14$ and $16.4^{\circ} \mathrm{C}$ in $\mathrm{B} 17$.

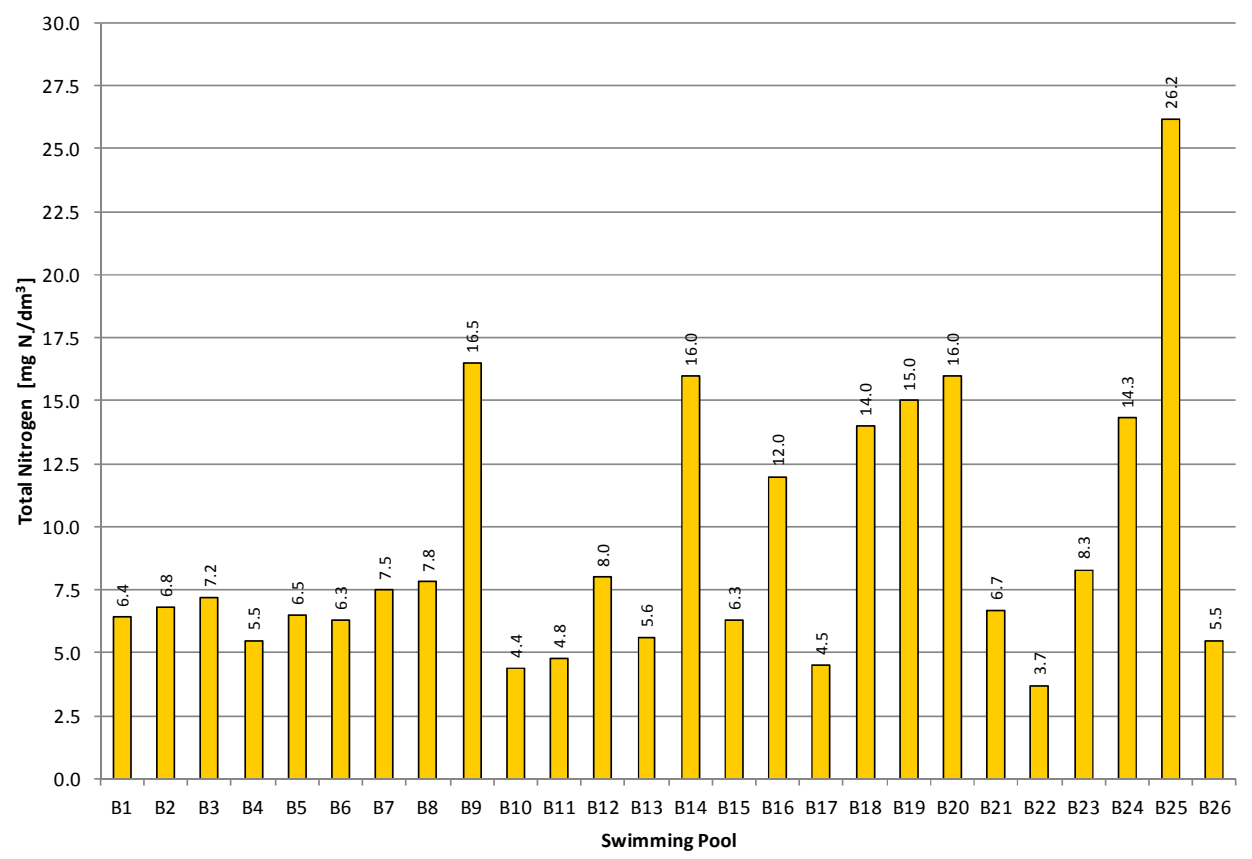

Fig. 7. The content of total nitrogen in the washings discharged from tested pools

Due to strong oxidising properties of free chlorine, its concentration in wastewater discharged to water and soil should not be higher than $0.2 \mathrm{mg} \mathrm{Cl} / \mathrm{dm}^{3}$. Just like with temperature, the concentration of free chlorine in the washings depended on the type of water used for rinsing. In washings from cycles with diatomaceous earth (B14 and B17), the concentration of free chlorine was very low and amounted to, respectively, 0.16 and $0.15 \mathrm{mg} \mathrm{Cl}_{2} / \mathrm{dm}^{3}$. The concentrations of free chlorine in the remaining washings were varying considerably, ranging from $0.21 \mathrm{mg} \mathrm{Cl} / \mathrm{dm}^{3}$ in $\mathrm{B} 19$ to $0.94 \mathrm{mg} \mathrm{Cl} / \mathrm{dm}^{3}$ in B16 (Fig. 8). Such high concentrations of free chlorine make direct discharge of washings from swimming pool circuits into water or soil impossible. Just like in the case of exceeded content of suspended solids, time is needed for the concentration of free chlorine to decrease to the acceptable level of $0.2 \mathrm{mg} \mathrm{Cl} / \mathrm{dm}^{3}$. Due to the fact that the beds are rinsed during evening hours, the next determination of free chlorine in the washings samples was done after 12 hours. The reduction of free chlorine ranged from $37.9 \%$ in B3 to $94.7 \%$ in $\mathrm{B} 2$, and the content of chlorine in the washings samples ranged from 0.02 to 
$0.20 \mathrm{mg} \mathrm{Cl}_{2} / \mathrm{dm}^{3}$. In the case of washings from B3, B10, B15 and B22, the content of free chlorine was determined after 2 hours and amounted to, respectively: $0.18 ; 0.15 ; 0.12$ and $0.18 \mathrm{mg} \mathrm{Cl}_{2} / \mathrm{dm}^{3}$ (Fig. 8).

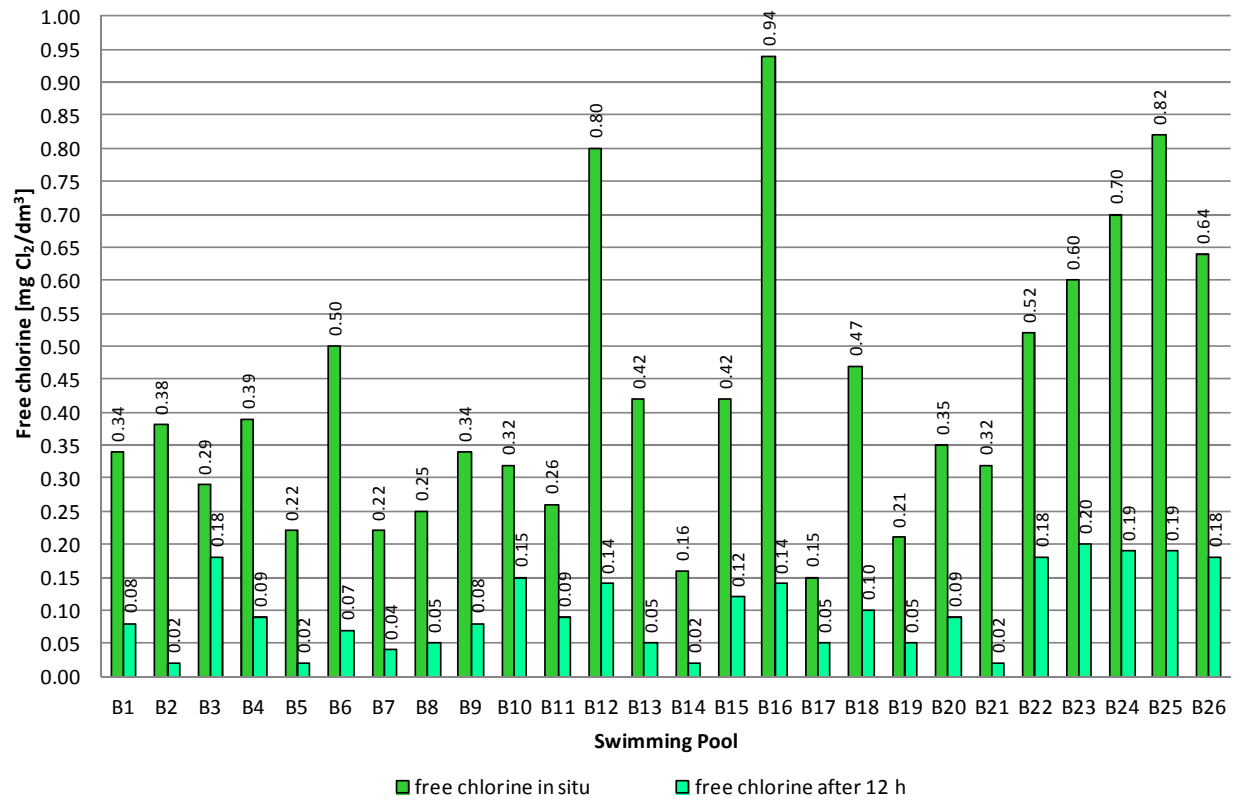

Fig. 8. The content of free chlorine in the washings during the sampling and after 12 hours

\section{Summary and conclusions}

The performed tests showed that washings discharged from swimming pools must not be directly discharged to water and soil due to the exceeded content of suspended solids and free chlorine concentration.

The results of the settling tests in Imhoff tank proved that a two-hour period of sedimentation allowed for the reuse of supernatants in 19 out of 26 tested cycles. In 7 circuits, the sedimentation process could be facilitated, for instance by dispensing and mixing washings with appropriate flocculant.

It needs to be underlined that the high efficiency of sedimentation of suspended solids in the washings in the majority of tested pool cycles was achieved by appropriate water coagulation in pool cycles and proper operation of filters.

The performed analysis of basic indicators identifying the contamination level of washings ( $\mathrm{pH}$, temperature, $\mathrm{COD}, \mathrm{BOD}_{5}, \mathrm{TP}, \mathrm{TN}$, free chlorine) and comparing them with the limits of contamination for sewage discharged to water and soil proved that it is possible to relieve the sewers and manage supernatant water from pool installations locally, for instance, by using it to irrigate green areas in an environmentally friendly way.

The results of the performed tests showed that:

- volume and quality of washings discharged from pools filtration circuits was varying and depended on the volume of water used for rinsing and the manner of pool circuit 
operation, ie on filtration cycle time, number of filters in circuits, their efficiency and bed type;

- washings discharged from tested pools installations must not be managed directly primarily due to the content of total suspended solids exceeding $35 \mathrm{mg} / \mathrm{dm}^{3}$ and the content of free chlorine exceeding $0.2 \mathrm{mg} \mathrm{Cl}_{2} / \mathrm{dm}^{3}$;

- sedimentation process allows for reuse of supernatant water, for instance, by using it to irrigate green areas or discharging it to a watercourse;

- a two-hour sedimentation process was, in the majority of cases, enough to reduce the amount of suspended solids and the values of indicators used to determine the amount of suspended solids, ie $\mathrm{COD}$ and $\mathrm{BOD}_{5}$, as well as the free chlorine content in supernatant water;

- both $\mathrm{pH}$ and temperature of washings did not exceed the limits specified for wastewater that can be discharged to water or soil;

- analysis of the volume of washings (from $28 \mathrm{~m}^{3} / \mathrm{month}$ in B14 to $547 \mathrm{~m}^{3} / \mathrm{month}$ in B21) and the costs of discharging them to the sewage system (from $296 \mathrm{PLN} / \mathrm{month}$ in B9 and 3818 PLN/month in B16) suggests that reusing supernatant water is reasonable and economically justifiable;

- in every case, water recovered from washings could be used for the replenishment of water in pools circuits if appropriate processes and devices (eg ultrafiltration, reverse osmosis) were used after the sedimentation process [30-33].

\section{References}

[1] Filter Backwash Recycling Rule. Technical Guidance Manual. Office of Ground Water and Drinking Water (4606M). EPA 816-R-02-014. www.epa.gov/safewater, 2002.

[2] Reissmann FG, Uhl W. Ultrafiltration for the reuse of spent filter backwash water from drinking water treatment. Desalination. 2006;198:225-235. DOI: 10.1016/j.desal.2006.03.517.

[3] Tobiason JE, Edzwald JK, Gilani V, Kaminski GS, Dunn HJ, Galant PB. Effects of waste filter backwash recycle operation on clarification and filtration. J Water Supply: Research and Technology-AQUA. 2003;52(4):259-275. http://aqua.iwaponline.com.

[4] Binnie Ch, Kimber M, Smethurst G. Basic Water Treatment. London, UK: Thomas Telford Publishing; 2002.

[5] Pizzi NG. Water Treatment. IV Edition. Denver, USA: AWWA; 2010. http://www.awwa.org/portals/0/files/ publications/documents/toc/WSOWaterTreatment4eTOC.pdf.

[6] Cornwell DA, Water Treatment Residuals Engineering. Denver, USA: AWWA Research Foundation and AWWA; 2006. http://search.library.utoronto.ca/details?6753783\&uuid=eb20f722-d4cd-4890-8b4db07f9bc47401.

[7] Walsh ME, Lake CB, Gagnon GA. Strategic pathways for the sustainable management of water treatment plant residuals. J Environ Eng Sci. 2008;7:45-52. https://www.researchgate.net/profile/Graham_Gagnon/ publication/237152295_Strategic_pathways_for_the_sustainable_management_of_water_treatment_plant_re siduals/links/551b36c60cf2fdce8438865c.pdf.

[8] Weiying L, Yuasa A, Bingzhi D, Huiping D, Naiyun G. Study on backwash wastewater from rapid sand-filter by monolith ceramic membrane. Desalination. 2010;250:712-715. DOI: 10.1016/j.desal.2008.11.028.

[9] Caniani D, Masi SI, Mancini M, Trulli E. Innovative reuse of drinking water sludge in geo-environmental applications. Waste Manage. 2013;33:1461-1468. DOI: 10.1016/j.wasman.2013.02.007.

[10] Arendze S, Sibiya M. Filter backwash water treatment options. J Water Reuse Desalination. 2014;4(2):85-91. DOI: 10.2166/wrd.2013.131.

[11] Wyczarska-Kokot J, Piechurski F. Ocena filtracji i stopnia zanieczyszczenia wód popłucznych w instalacjach basenowych (Assessing the efficiency of water filtration and the quality of washings in swimming pools). Ochr Środ. 2002;1(84):33-36. http://www.os.not.pl/docs/czasopismo/2002/Wyczarska_1-2002.pdf. 
[12] Wyczarska-Kokot J. Badania możliwości zagospodarowania popłuczyn z obiegów basenowych. (The study of possibilities of washings reusing from swimming pool circulation systems). Proc ECOpole. 2015;9(2):803-813. DOI: 10.2429/proc.2015.9(2)091.

[13] DIN 19643 1-4:2012-11: Aufbereitung von Schwimm und Badebeckenwasser (Treatment of water of swimming pools and baths); 2012.

[14] ANSI/APSP-11 2009: American National Standard for water quality in public pools and spas. http://standards.nsf.org/apps/group_public/download.php/17496/ANSI-APSP-11\%202009-for-apspstore.pdf.

[15] Guidelines for safe recreational water environments. Vol. 2: Swimming pools and similar environments. WHO, 2006. http://www.who.int/water_sanitation_health/bathing/srwe2full.pdf.

[16] Pool Water Treatment Advisory Group (PWTAG). Dedicated solely to raising standards in swimming pool water treatment. UK; 2015. http://pwtag.org/code-of-practice-feb-2015/.

[17] Indoor swimming pools in Poland - the inventory of sports facilities. The Department of Sports Infrastructure of Sport and Tourism Ministry, Warszawa 2015. https://s3-eu-west-1.amazonaws. com/fs.siteor.com/msport/files/badania\%20i\%20analizy/Infrastruktura/Plywalnie.pdf?1447760951.

[18] Teo TLL, Coleman HM, Khan SJ. Chemical contaminants in swimming pools: Occurrence, implications and control. Environ Internat. 2015;76:16-31. http://dx.doi.org/10.1016/j.envint.2014.11.012.

[19] Korkosz A, Janczarek M, Aranowski R, Rzechuła J, Hupka J. Efficiency of deep bed filtration in treatment of swimming pool water. Physicochem Probl Miner Process. 2010;44,103-113. http://www.minproc.pwr.wroc.pl/journal/pdf/2010/FPM\%2044/KORKOSZ.pdf.

[20] Korkosz A, Niewiadomski M, Hupka J. Investigation of properties of swimming pool water treatment sediments. Physicochem Probl Miner Process. 2011;46:243-252. http://www.minproc.pwr.wroc.pl/ journal/pdf/ppmp46.243-252.pdf.

[21] Council Directive 86/280/EEC of 12 June 1986 on limit values and quality objectives for discharges of certain dangerous substances. http://eur-lex.europa.eu.

[22] Directive 2000/60/EC of the European Parliament and of the Council of 23 October 2000 establishing a framework for Community action in the field of water policy. http://eur-lex.europa.eu.

[23] Directive 2008/105/EC of the European Parliament and of the Council of 16 December 2008 on environmental quality standards in the field of water policy. http://eur-lex.europa.eu.

[24] Rozporządzenie Ministra Środowiska z dnia 18 listopada 2014 r. w sprawie warunków, jakie należy spełnić przy wprowadzaniu ścieków do wód lub do ziemi (Regulation of Environment Minister of 18 November 2014, on conditions to be met when discharging sewage to waters or to the soil). DzU 2014, poz. 1800. http://isap.sejm.gov.pl/DetailsServlet?id=WDU20140001800.

[25] Directive 2006/118/EC of the European Parliament and of the Council of 12 December 2006 on the protection of groundwater against pollution and deterioration. http://eur-lex.europa.eu.

[26] Gautam Kaul A, Kaul SN. Water and Wastewater Analysis. New Delhi, India: Daya Publishing House; 2002.

[27] Tomar M. Quality Assessment of Water and Wastewater. Boca Raton, Florida: CRC Press; 1999.

[28] Kaul K. Handbook of Water and Wastewater Analysis. New Delhi, India: Atlantic Publishers and Dist; 2007.

[29] Down RD, Lehr JH. Environmental Instrumentation and Analysis Handbook. New Jersey: Wiley; 2005.

[30] Reissmann FG, Schulze E, Albrecht V. Application of a combined UF/RO system for the reuse of filter backwash water from treated swimming pool water. Desalination. 2005;178:41-49. DOI: 10.1016/j.desal.2004.11.027.

[31] Barbot E, Moulin P. Swimming pool water treatment by ultrafiltration-adsorption process. J Membr Sci. 2008;314(1-2):50-57. DOI: 10.1016/j.memsci.2008.01.033.

[32] Baker R.W. Membrane Technology and Applications. West Sussex: Wiley; 2012. DOI: 10.1002/9781118359686.

[33] Reissman FG, Uhl W. Ultrafiltration for the reuse of spent filter backwash water from drinking water treatment. Desalination. 2006;198(1-3):225-235. DOI: 10.1016/j.desal.2006.03.517. 